\title{
Weight Loss and Fingolimod
} Kilo Kaybı ve Fingolimod

\author{
Nefati Kiylioglu \\ Adnan Menderes University Faculty of Medicine, Department of Neurology and Department of Clinical Neurophysiology, Aydin, Turkey
}

Keywords: Obesity, weight loss, lymphopenia, fingolimod, multiple sclerosis

Anahtar Kelimeler: Obezite, kilo kaybı, lenfopeni, fingolimod, multipl skleroz

Dear Editor,

Fingolimod (FTY720) is a functional antagonist of the SP1 receptor on lymphocytes, blocking its egress from the lymph nodes and acting as an immunosuppressant (1). During its treatment, mild-moderate degree weight loss was observed in three cases. No reason was found except current fingolimod treatment.

\section{Case 1}

A 34-year-old woman had had relapsing-remitting multiple sclerosis (RRMS) for 13 years. Her treatment was switched from interferon beta-1a intramuscular (2003-2014) to fingolimod because of the increased Expanded Disability Status Scale (EDSS) score (0 to 1.5). After ten months, she reported weight loss of approximately $24 \mathrm{~kg}$ (from 75 to $51 \mathrm{~kg}$ : $32 \%$ ) over the previous six months. Her body mass index (BMI) was still normal (21.5 $\mathrm{kg} / \mathrm{m}^{2}$ ). Baclofen and modafinil were accompanying drugs in the treatment but they were started before fingolimod treatment. The lymphocyte count dropped to $680 /$ microliter in the fourth month after the onset of treatment and remained at similar levels thereafter.

\section{Case 2}

A 50-year-old woman had had RRMS for nine years (EDSS=6). Her treatment was switched from interferon beta-1a subcutaneous (SC) three times a week (2007-2013) to fingolimod because of the increased EDSS (2 to 4). She was diagnosed as having epilepsy in 2001 and she was on carbamazepine $400 \mathrm{mg} /$ day and gabapentine $1200 \mathrm{mg} /$ day. She reported weight loss of approximately $10 \mathrm{~kg}$ (62 kg to $52 \mathrm{~kg}: 16 \%$ ) during the previous six months. Similar to case 1 , weight loss started at around twelve months after the initiation of fingolimod. Her BMI was normal $\left(19.1 \mathrm{~kg} / \mathrm{m}^{2}\right)$. The lymphocyte count dropped to 150 /microliter in the ninth month after the onset of treatment and remained below 530/microliter thereafter.

Case 3

A 34-year-old woman had had RRMS for 16 years $($ EDSS $=4$ ). Her treatment was switched first from interferon beta-1b SC every other day (2005-2008) to glatiramer acetate (2008-2014), and later to fingolimod because of the frequent attacks and the increased EDSS (1 to 4). Weight loss was not limited to the time period when she was on fingolimod. She also had weight loss of approximately $10 \mathrm{~kg}$ during the first two treatments $(60 \mathrm{~kg}$ to 50 $\mathrm{kg}: 16 \%)$. Fingolimod-related weight loss was $4 \mathrm{~kg}$ (50 kg to 46 $\mathrm{kg}: 8 \%)$. Weight loss started twelve months after the initiation of fingolimod and her BMI was below normal $\left(16.7 \mathrm{~kg} / \mathrm{m}^{2}\right)$. The lymphocyte count dropped to $80 /$ microliter in the seventh month after the onset of treatment and remained below 630/microliter thereafter.

\footnotetext{
Address for Correspondence/Yazışma Adresi: Nefati Kiylioglu MD, Adnan Menderes University Faculty of Medicine, Department of Neurology and Department of Clinical Neurophysiology, Aydin, Turkey

Phone: +90 5325165188 E-mail: knefati@gmail.com ORCID ID: orcid.org/0000-0001-5783-1719

Received/Geliş Tarihi: 12.03.2017 Accepted/Kabul Tarihi: 15.06.2017

${ }^{\circ}$ Copyright 2017 by Turkish Neurological Society

Turkish Journal of Neurology published by Galenos Publishing House.
} 


\section{Discussion}

Weight loss due to fingolimod has been reported in an animal study conducted on cynomolgus monkeys. Animals receiving FTY720 at $0.3 \mathrm{mg} / \mathrm{kg}$ doses lost $3-19 \%$ of their body weight. Weight loss was only partly reversed in this study despite discontinuation of the drugs, and lymphocyte and leukocyte counts were the only hematologic abnormalities observed in the monkeys (2). In mice, FTY720 normalized hyperglycemia by stimulating pancreatic beta cell regeneration (3). In addition, FTY720 inhibited adipogenesis and stimulated adipose tissue lipolysis, and therefore was proposed in this study as an anti-obesity drug (4).

The immune and metabolic systems share many basic cellular pathways. The same hormones, cytokines, proteins, transcription factor, and bioactive lipids act in metabolic and immune pathways. In fact, obesity is characterized by a low level of inflammation, insulin resistance, and fatty liver. The accumulation of lipids in adipose tissue leads to the accumulation of macrophages in the same area; the release of cytokines from the macrophages inhibits the activity of insulin at the post receptor level in the cell and results in insulin resistance (5). These are proof of immune activation leading to obesity in animals and partly help to understand why immunosuppressant drugs lead to weight loss in animals. In our patients, fingolimod worked as an immunosuppressant because of the lymphocyte counts that dropped and stayed below normal levels. It is unclear, why that effect has not been extensively reported in clinical studies. The first reason may be that it may be related to biologic diversity. All related studies have been performed on animals and there have been no human studies for obesity, insulin resistance or diabetes mellitus. The second reason may be that researchers and patients may not pay attention to weight loss. Weight may not be screened or followed-up in clinical trials because it is not mentioned. Two thirds of patients were female in these trials and they might not have mentioned this favorable side effect of fingolimod.

\section{Ethics}

Peer-review: Internally peer-reviewed.

Financial Disclosure: The author declared that this study received no financial support.

\section{References}

1. Willis MA, Cohen JA. Fingolimod Therapy for Multiple Sclerosis. Semin Neurol 2013;33:37-44.

2. Quesniaux VF, Menninger K, Kunkler A, Vedrine C, Bernhard M, Hedinger $\mathrm{R}$, Kraus G, Schuurman HJ. The novel immunosuppressant FTY720 induces peripheral lymphodepletion of both T- and B-cells in cynomolgus monkeys when given alone, with Cyclosporine Neoral or with RAD. Transpl Immunol 2000;8:177-187.

3. Zhao Z, Choi J, Zhao C, Ma ZA. FTY720 Normalizes Hyperglycemia by Stimulating $\beta$-Cell in Vivo Regeneration in $\mathrm{db} / \mathrm{db}$ Mice through Regulation of Cyclin D3 and p57 KIP2. J Biol Chem 2012;287:5562-5573.

4. Moon MH, Jeong JK, Lee JH, Park YG, Lee YJ, Seol JW, Park SY. Antiobesity activity of a sphingosine 1-phosphate analogue FTY720 observed in adipocytes and obese mouse model. Exp Mol Med 2012;44:603-614.

5. Wellen KE, Hotamisligil GS. Inflammation, stress, and diabetes. J Clin Invest 2005;115:1111-1119. 